\title{
Fertility of Uncontrolled Village Flock Eggs and Comparison of Quality Traits of Table-Eggs Produced in Different Production Systems
}

\author{
Musa Sarıca ${ }^{1, a}$, Kadir Erensoy ${ }^{1, b, *}$, Ayşe İpek Özsoy ${ }^{2, c}$ \\ ${ }^{1}$ Department of Animal Science, Agricultural Faculty, Ondokuz Mayis University, 55139 Atakum, Samsun, Turkey \\ ${ }^{2}$ Sinop Directorate of Provincial Agriculture and Forestry, Boyabat Directorate of District Agriculture and Forestry, 57200 Sinop, Turkey
} *Corresponding author

\section{A R T I C L E I N F O A B S T R A C T}

Research Article

In this study, the eggs produced in uncontrolled village conditions were compared to free-range, organic and cage-system in two seasons, in autumn and spring, in terms of external and internal quality traits. In the autumn and spring period, 110 eggs were collected from the village eggs and 50 eggs from other production systems. In order to determine the fertility in the village eggs, 60 eggs were placed in a laboratory type incubator in both seasons and fertility control was made at the 18th day. All data of egg quality traits were performed by taking the average of the two seasons. Egg shape index, shell ratio, shell thickness, shell cleanness, shell defects, albumen and yolk traits differed significantly among production system. The lowest shape index, shell thickness and shell cleanness were found in village eggs. Higher shell rates were determined from eggs in cage and organic production compared to others. The yolk height and yolk index were the lowest and the yolk colour was the darkest in the white cage eggs. Brown cage eggs showed the better results in the majority of their quality traits. However, they had a higher meat and blood-spot level than other systems. In addition, the presence of cockerels in the village flocks caused the fertile eggs and approximately $85 \%$ fertility was obtained. Our results showed that it has become obvious that the village hen and free-range hen eggs which can be marketed in high prices compared to the commercial eggs, have no superiority in terms of the traits they are considered. Besides, as they are significantly fertile, especially in hot summer months, according to storage duration and conditions, the probability of embryo development for these eggs has turned to be of high importance for consumption.

Egg quality

Production systems

Free-range

Organic

Cage-system

b|kadir.erensoy@omu.edu.tr

(iD) http://orcid.org/0000-0001-5331-0596

This work is licensed under Creative Commons Attribution 4.0 International License

\section{Introduction}

Poultry production has advanced rapidly over the past three decades, with modern production methods and improved hybrid material. Egg production increased per hen from 240 - 250 to 340 - 350; egg weight from 58.2 to $65 \mathrm{~g}$ between 1950 - 2000 years (Sarıca et al., 2018a). Despite the advance in egg sector, some of the poultry flocks in the world is still reared under extensive conditions. High input costs limit intensive production, especially in undeveloped countries. Although the egg and meat yields are low and the mortality rate is high, the production continues with different applications. It is aimed to meet the need for animal protein from poultry in rural areas and to provide partial income from excess products (Alders and Pym, 2009; FAO, 2019).

Village hens stand out with the tendency of consumers to accept their products as healthy and high quality. As there is no control in production, it is possible for hens to access all kinds of materials, chemicals and other wastes. However, with the image that the eggs produced are of higher quality, village eggs can be sold at a price 2 - 3 times higher than commercial eggs. In a field study, it was stated that although the respondents did not know how the production was made, they wanted to consume village eggs with a great rate of $83.25 \%$ (Mizrak et al., 2012).

There is no possibility to define village poultry as a production system, and there are also big differences among applications. On the other hand, some of the laying hens that have completed their commercial production lifetime may be moved to the villages and marketed as village hen. For this reason, it is not possible to see all the flocks in the villages as certain gene resources (Sarica, 2017; Sarica et al., 2018a). Depending on the marketing and 
consumer demands, the egg production, which took place in the closed or open floor system in the 1960s, has changed rapidly over time. Especially since the 1960s, the use of the traditional cage system in egg production has increased the amount and capacity immensely. However, as of 1970's, the cage system has started to be questioned and issues related to animal welfare have come to the agenda (Blokhuis and van Niekerk, 2005). These issues have been discussed in the European Union countries for many years, different sanction decisions have been taken regarding cage systems, and the traditional cages were banned in EU in 2012. In the enriched cage systems used, there were decreases in production due to the increased costs (Mench et al., 2011; Sarica et al., 2018a).

Hens reared in enriched cage systems are generally considered to be freer and more interpreted as a better level of welfare compared to conventional cages, since hens housed in cage-free systems are more likely to move. However, some risks that worsen animal welfare are either absent or very rare in cage systems. On the other hand, all studies and data obtained in commercial production are stated to provide the most economical and hygienic production of traditional cage system (Mench et al., 2011). Alternative systems to the cage in egg production can vary from floor system to organic production. The most extreme point of production is "village poultry, whose boundaries cannot be determined". This system is able to range in the area they want the hens in a completely uncontrolled conditions in Turkey and many other countries, is with the producers of the rural areas have varying practices from region to region (Sarıca, 2017; Sarica et al., 2018b).

In the share of village poultry meat and egg production in Turkey, despite the decline in recent years due to Avian Influenza, it is still important. Among the 21.5 - 22.0 billion eggs produced, 2.0 - 2.2 billion eggs (about 10\%) are mentioned as an unregistered or village egg produced and marketed (Yum-Bir, 2018). It is not possible to increase village egg production in a short time in line with consumer demands. Dirty eggs in commercial production may be delivered to the consumers as village eggs in straw (Sarica, 2017; Sarica et al., 2018b).

Since natural incubation is still used in village flocks, one or more cockerels are kept with 10 - 15 hens. Even if the eggs obtained in village flocks are not incubated, the presence of a cockerel in the flocks are seen as a part of the production. It is observed that hens are kept together with the cockerels in some small-capacity farms producing freerange eggs. Especially in eggs produced and stored in the hot summer, embryo development may occur (Sarica et al., 2018b). Despite the differences between the results, the ratio of shell contamination and broken-cracked eggs are higher in floor and open systems. In addition, feather pecking, feathering and cannibalistic deaths may be higher in floor, open and aviary systems (Şekeroğlu et al., 2018).

In this study, village eggs produced under uncontrolled conditions and controlled free-range, organic, and cage system eggs were compared with the external and internal quality traits in the autumn and spring periods. In addition, a group of village eggs were placed in the incubator, and the embryo development was determined at the 18th days of incubation and the eggs were determined as fertile. It is believed that the results of this study will provide a direct information for the consumers. Especially in village egg production, where fertile eggs are obtained, the development of embryo due to storage temperature is a serious risk in marketing. In addition, it was aimed to contribute to correcting false perceptions by revealing egg quality traits that concern the consumer closely.

\section{Materials and Methods}

Quality traits of the eggs produced in different production systems were determined in October (autumn), and May (spring). However, the average of two seasons was used in the evaluations. Village eggs were bought from the same producers that had $50-100$ chickens in both seasons and produced with the uncontrolled-traditional system. Free-range and organic system eggs were provided from a certified farm in Samsun. Cage eggs (white and brown) were also purchased from a farm in Samsun, which has a conventional (battery type) cage system. The production dates of the eggs were provided on the same day in both periods. On the other hand, it is ensured that the flock ages were close to each other in both periods. However, since there was no possibility to determine the age in the village flocks, the younger chickens were preferred.

In the autumn and spring period, 110 eggs were taken from the village eggs and 50 eggs from other production systems. In order to determine the fertility rate in the village eggs, 60 eggs were placed in a laboratory type incubator in both seasons and fertility control was made under light at the 18th day of incubation. Eggs without embryo development were broken and early-stage embryonic deaths were determined and real fertility rate was calculated (Elibol, 2018). While choosing the farm with free-range system, attention was paid not to have a cockerel. External and internal quality traits of 50 eggs taken in each season from other production systems were determined.

Egg weight, shape index, shell traits (weight, cleanness, color, defect, thickness, breaking strength, density), albumen traits (height, length, width, $\mathrm{pH}$ ) and yolk traits (height, diameter, weight, color, $\mathrm{pH}$ ) and meat-blood spots were determined as quality traits.

After the eggs were kept at room temperature (18 $24^{\circ} \mathrm{C}$ ) for 24 hours, their weights were determined with 0.1 $\mathrm{g}$ precision scale. By measuring the width and length of the egg with a digital caliper, the shape index was calculated. Density was determined according to the different density salt-water solutions. For this purpose, 9 salt-water solutions with a density of 1.060 to $1.100 \mathrm{~g} / \mathrm{L}$ were used (Altan, 2015; Sarıca and Erensayın, 2018). The breaking strength of the egg shell was measured with egg-shell breaking strength gauge in $\mathrm{kg} / \mathrm{cm}^{2}$. The shell thicknesses were measured on two non-membrane shell samples taken from the middle region of the egg via micrometer in $\mathrm{mm}$. Internal quality traits were determined on the glass table with mirror. Eggs were broken on the glass table and were waited for 10 minutes and then albumen width, length and yolk diameter were measured with digital caliper in $\mathrm{mm}$. Subsequently, the height of albumen was measured with a tripod micrometer in $\mathrm{mm}$, and the data used in calculating the albumen index $(\%)$ and Haugh Unit were obtained. The yolk height $(\mathrm{mm})$ was measured from the highest point of the yolk and the yolk index (\%) was calculated. 
Meat and blood spots were detected (exist or absent) on the glass table and in the egg albumen and yolk from the mirror image below. The yolk color was determined by the Roche Color Range, which has 15 yellow shades. Albumen and yolk $\mathrm{pH}$ values were measured with $\mathrm{pH}$ meter (Altan, 2015; Sarıca and Erensayın, 2018).

Scoring between 0-2 was used to determine the shell color and 0 score; light, 1; medium brown; 2 expresses dark brown. A score of 0 to 4 was made for the shell cleanness, 0 (zero) was referred to the cleanest and 4 was the dirtiest shell. Scores indicated that between 0 and 4 were made for visible defects in the shell. In this scoring, 0 ; no defect, 1; spotted, 2; rough, 3; presence of transparent areas and the micro cracks, and 4; excessively spotted, roughed and cracked.

Normality analysis was carried out with Shapiro-Wilk test in order to determine the suitability of the data for variance analysis. It was determined that the data showed normal distribution $(\mathrm{P}>0.05)$. In the evaluation of the traits that fulfill the assumptions, variance analysis was performed to reveal the production systems. All data of egg quality traits were performed by taking the average of the two seasons. Tukey multiple comparison test was used to compare the means. Non-parametric Kruskal Wallis test was used to compare the discrete values expressed by score and \%, and Mann-Whitney U test was used to compare the means (Özdamar, 2002). SPSS package program (Verison 16) was used in the analysis.

\section{Results and Discussion}

Eggs taken from village flocks and placed in the incubator for the purpose of determining fertility were those with embryo development by light control at the 18th days of incubation. In the autumn period, the fertility rate of the village eggs was $76.6 \%$ and the actual fertility rate was $85.0 \%$ according to the light control. In the spring period, fertility rates were found $71.7 \%$ and $83.3 \%$, respectively. From these data, the average fertility rates were $74.2 \%$ compared to the light control, while the actual fertility was $84.2 \%$. This level is close to the values obtained in egg and meat-type poultry production (Elibol, 2018).

For this reason, it should be taken into consideration that the results related to quality traits of village eggs are determined to a large extent in fertile eggs. Considering that the eggs were collected by traditional methods in the egg production and marketing system of the village hens and placed on the market in certain periods, fertility of eggs poses a serious problem. Embryo development may take place at different levels during periods when the ambient temperature is higher than $24^{\circ} \mathrm{C}$ (Sarica et al., 2018b). This situation, which poses serious risks in terms of egg consumption, is also important for farms with cockerels in the free-range production system.

All quality traits except the density were found statistically different among production systems $(\mathrm{P}<0.01$, Table 1). It may be said that genotype and age are important in differences between production systems in terms of egg weight, shape index, shell, albumen and yolk ratios. Especially in commercial production, egg production is planned with the beginning of August to September, so autumn eggs are smaller. Although there is a similar structure in village hens, the fact that old hens are always in the flock balances the egg weight. It has been reported that the effect of production systems on egg weight is important (Sarica and Erensayın, 2018). It is stated that hens reared in the free-range system give eggs lighter than other systems (Mostert et al., 1995). In studies comparing the traditional cage and free-range system, Van den Brand et al. (2004) and Wang et al. (2009) reported that free-range eggs were heavier, on the contrary, Samiullah et al. (2014) reported that cage eggs were heavier. Hidalgo et al. (2008) stated that egg weight was the highest in organic system, whereas cage eggs had the lowest weight, followed by the floor and free-range production systems, respectively. In contradiction with these findings, Minelli et al. (2007) found that egg weight was higher in traditional cages compared to organic system. Kılıç and Şimşek (2006) stated that egg weight can vary according to the laying season and the difference between egg weights obtained in summer and winter periods is important $(\mathrm{P}<0.01)$. They found a positive relationship between temperature and egg weight in the summer period and a negative relationship in the winter period. Artan and Durmuş (2015) reported that eggs produced under commercial and village conditions were heavier than eggs produced in the free-range system.

In the current study, egg shape index varied according to production systems $(\mathrm{P}<0.01)$. The closest results to the village eggs $(74.00 \%)$ with the lowest shape index were determined from the white eggs in the cage system (75.22\%). The shape index is a criterion that defines the oval-ellipsoidic structure of the eggs. In general, eggs with a shape index less than 72 were considered long, and eggs larger than 76 were round. The shape index in eggs is 74, which is the most natural expression of the shape (Sarica and Erensayin, 2018). When eggs (long and very round) outside this range were placed in viols with eggs of the same weight group, breaks occur due to the uneven distribution of weight. Artan and Durmuş (2015) reported that the shape index of village eggs was lower than commercial and free system eggs. Although there were some differences in the studies, the heritability of the egg shape was quite high, and the environmental factors were low in commercial production except for negative environmental conditions, diseases and malnutrition (Türkoğlu and Sarıca, 2018).

While the shell thickness of the eggs was found different among the production systems, the village eggs had the lowest values $(\mathrm{P}<0.01)$. Lolli et al. (2013) reported that shell thickness was higher in organic eggs compared to cage eggs. However, in some studies, it was found that there was no significant difference between the shell thicknesses of eggs produced in free-range and cage system van (Den Brand et al., 2004; Wang et al., 2009). It is desired that the breaking strength is $2.7-3.6 \mathrm{~kg} / \mathrm{cm}^{2}$ and the thickness at each point of the shell is at least $0.33 \mathrm{~mm}$. There are positive relationships between shell thickness, breaking strength and density. For this reason, density is taken into consideration in selection studies since it also has some traits related to internal quality. However, the breaking strength of eggs with thick shells is not always high. On the other hand, density is important in terms of representing both internal and external quality and it is one of the best criteria for the freshness of the egg (Şekeroğlu, 2002; Türkoğlu and Sarıca, 2018) 
Table 1. Some quality traits of eggs produced in different production systems

\begin{tabular}{|c|c|c|c|c|c|c|c|}
\hline Traits & Village eggs & Free-Range & Cage-Brown & Cage-White & Organic & SEM & $\mathrm{P}$ \\
\hline \multicolumn{8}{|l|}{ General egg traits } \\
\hline Egg weight (g) & $59.45^{\mathrm{b}}$ & $59.77^{\mathrm{b}}$ & $60.81^{\mathrm{b}}$ & $61.20^{\mathrm{b}}$ & $64.40^{\mathrm{a}}$ & 0.399 & $* *$ \\
\hline Shape index $(\%)$ & $74.00^{c}$ & $76.11^{\mathrm{ab}}$ & $77.33^{\mathrm{a}}$ & $75.22^{\mathrm{bc}}$ & $76.31^{\mathrm{ab}}$ & 0.213 & $* *$ \\
\hline Shell ratio $(\%)$ & $10.92^{c}$ & $10.98^{c}$ & $12.54^{\mathrm{a}}$ & $12.37^{\mathrm{a}}$ & $11.86^{\mathrm{b}}$ & 0.085 & $* *$ \\
\hline Albumen ratio (\%) & $61.48^{\mathrm{b}}$ & $62.52^{\mathrm{ab}}$ & $63.39^{c}$ & $59.89^{\mathrm{c}}$ & $62.44^{\mathrm{ab}}$ & 0.198 & $* *$ \\
\hline Yolk ratio $(\%)$ & $27.60^{\mathrm{a}}$ & $26.49^{\mathrm{b}}$ & $24.06^{\mathrm{c}}$ & $27.73^{\mathrm{a}}$ & $25.69^{b}$ & 0.187 & $* *$ \\
\hline Density (g/L) & $1.080^{\mathrm{b}}$ & $1.080^{\mathrm{b}}$ & $1.090^{\mathrm{a}}$ & $1.090^{\mathrm{a}}$ & $1.090^{\mathrm{a}}$ & 0.001 & NS \\
\hline \multicolumn{8}{|l|}{ Shell traits } \\
\hline Breaking strength $\left(\mathrm{kg} / \mathrm{cm}^{2}\right)$ & $1.83^{\mathrm{c}}$ & $2.17^{\mathrm{bc}}$ & $3.18^{\mathrm{a}}$ & $3.16^{\mathrm{a}}$ & $2.60^{\mathrm{b}}$ & 0.092 & $* *$ \\
\hline Shell thickness (mm) & $0.315^{\mathrm{d}}$ & $0.335^{\mathrm{c}}$ & $0.364^{\mathrm{b}}$ & $0.356^{\mathrm{b}}$ & $0.371^{\mathrm{a}}$ & 0.002 & $* *$ \\
\hline Shell cleanness ${ }^{* 1}$ & $0.62^{\mathrm{a}}$ & $0.43^{\mathrm{a}}$ & $0.15^{\mathrm{b}}$ & $0.15^{\mathrm{b}}$ & $0.00^{\mathrm{b}}$ & 0.043 & $* *$ \\
\hline Shell defects ${ }^{* 2}$ & $0.58^{\mathrm{a}}$ & $0.48^{\mathrm{a}}$ & $0.27^{\mathrm{a}}$ & $0.25^{\mathrm{a}}$ & $0.37^{\mathrm{a}}$ & 0.048 & NS \\
\hline Shell colour*3 & $0.92^{\mathrm{c}}$ & $1.50^{\mathrm{b}}$ & $1.95^{\mathrm{a}}$ & $0.00^{\mathrm{d}}$ & $1.96^{\mathrm{a}}$ & 0.010 & $* *$ \\
\hline \multicolumn{8}{|l|}{ Albumen Traits } \\
\hline Albumen height (mm) & $6.08^{b}$ & $5.68^{\mathrm{b}}$ & $7.66^{\mathrm{a}}$ & $6.03^{b}$ & $6.13^{\mathrm{b}}$ & 0.097 & $* *$ \\
\hline Albumen index & $7.70^{\mathrm{b}}$ & $6.31^{\mathrm{c}}$ & $9.74^{\mathrm{a}}$ & $6.73^{\mathrm{bc}}$ & $6.94^{\mathrm{bc}}$ & 0.163 & $* *$ \\
\hline Haugh Unit & $75.42^{b}$ & $73.35^{\mathrm{b}}$ & $86.22^{\mathrm{a}}$ & $75.79^{\mathrm{b}}$ & $74.48^{b}$ & 0.689 & $* *$ \\
\hline Albumen $\mathrm{pH}$ & $8.91^{b c}$ & $9.03^{\mathrm{a}}$ & $8.85^{\mathrm{c}}$ & $8.99^{\mathrm{ab}}$ & $8.84^{c}$ & 0.016 & $* *$ \\
\hline \multicolumn{8}{|l|}{ Yolk traits } \\
\hline Yolk height (mm) & $17.19^{\mathrm{b}}$ & $16.62^{c}$ & $17.61^{\mathrm{a}}$ & $16.54^{\mathrm{c}}$ & $17.22^{\mathrm{ab}}$ & 0.065 & $* *$ \\
\hline Yolk index & $40.69^{b}$ & $40.43^{\mathrm{b}}$ & $43.88^{\mathrm{a}}$ & $38.22^{\mathrm{c}}$ & $40.49^{\mathrm{b}}$ & 0.013 & $* *$ \\
\hline Yolk colour (1-15) & $7.90^{\mathrm{b}}$ & $7.63^{\mathrm{b}}$ & $11.65^{\mathrm{a}}$ & $11.10^{\mathrm{a}}$ & $5.67^{\mathrm{c}}$ & 0.012 & $* *$ \\
\hline Yolk pH & $6.15^{\mathrm{b}}$ & $6.05^{\mathrm{c}}$ & $6.02^{\mathrm{c}}$ & $6.01^{\mathrm{c}}$ & $6.24^{\mathrm{a}}$ & 0.013 & $* *$ \\
\hline \multicolumn{8}{|l|}{ Appearance } \\
\hline Meat spots ${ }^{* 4}$ & $0.17^{\mathrm{b}}$ & $0.73^{\mathrm{a}}$ & $0.23^{\mathrm{b}}$ & $0.01^{\mathrm{b}}$ & $0.81^{\mathrm{a}}$ & 0.011 & $* *$ \\
\hline Blood spots ${ }^{* 5}$ & $0.20^{\mathrm{c}}$ & $0.63^{b}$ & $0.27^{\mathrm{c}}$ & $0.01^{\mathrm{c}}$ & $0.88^{a}$ & 0.079 & $* *$ \\
\hline
\end{tabular}

${ }^{* 1}$ : 0 clean, 4 very dirty; ${ }^{* 2}$ : 0 normal, 4 very defective; ${ }^{* 3}: 0$ white, 1 light Brown, 2 brown; ${ }^{* 4}: 0$ no meat spot, 1 small meat spot, 2 two and more meat spots; ${ }^{* 5}$ : 0 no blood spot, 1 small blood spot, 2 two and more blood spots. SEM: Standart Error of Mean, **: P<0.01, NS: No significance (P>0.05).

In the study, the specific gravity of the eggs produced in different production systems ranged between 1.070 $1.090 \mathrm{~g} / \mathrm{L}$. Eggs with a specific gravity below 1.080 are considered to be weak-shelled (Şekeroğlu, 2002). In the study, higher breaking strength was determined in the eggs produced in the cage system, and the density was higher in the eggs produced from the cage and organic production systems $(\mathrm{P}<0.01)$. Artan and Durmuş (2015) reported that the specific weight of village eggs was significantly lower than eggs produced in commercial and free-range systems $(\mathrm{P}<0.01)$. Ekinci $(2013)$ reported that the breaking strength varied between $1.6-4.3 \mathrm{~kg} / \mathrm{cm}^{2}$.

The eggs produced in the free-range system and village hen flocks were found more dirty than other systems $(\mathrm{P}<0.01)$, and it was observed that uncontrolled environmental conditions were effective in this regard. Ferrante et al. (2009) reported that the rate of dirty eggs in free-range and organic production system is higher than in the traditional cage and floor system due to the excessive laying outside the nest. Schwarz et al. (1999) stated that the hens reared in the cages produced cleaner eggs than freerange hens. De Reu et al. (2009) reported that the rate of dirty eggs was higher in enriched cages (7.8\%) than other alternative systems (4.1\%).

The highest shell defect was observed in the village eggs, free-range and organic production systems $(\mathrm{P}<0.01$; Table 1). De Reu et al. (2005) reported the rate of cracked eggs in the cage-free systems (5.6\%) were at similar level to the cage system $(7.8 \%)$.

It has been observed that the production systems affect the shell color, and there was an important variation in the color in the cage and village eggs $(\mathrm{P}<0.01)$. This trait is influenced by management and feeding factors as well as its high inheritance (Türkoğlu and Sarıca, 2018).

Egg shell ratio was statistically different among production systems $(\mathrm{P}<0.01)$, higher shell rate was determined for eggs produced in cage and organic system than others $(\mathrm{P}<0.01$; Table 1). Hidalgo et al. (2008) reported that the shell ratio in cage eggs is higher than other alternative systems. On the other hand, the egg shell ratio is closely related to age, egg size and level of access to calcium resources (Kutlu, 2018).

In terms of production systems, differences between all yolk traits were found statistically significant $(\mathrm{P}<0.01$; Table 1). The yolk height and index were lower in the white cage eggs $(\mathrm{P}<0.01)$. While yolk was the lowest in organic eggs, free-range and village eggs have been followed by contrary to general beliefs, eggs in the cage system had the darkest yolk color $(\mathrm{P}<0.01)$. While yolk $\mathrm{pH}$ was higher in organic and village eggs $(\mathrm{P}<0.01)$, meat and blood spots were listed as organic, cage, free range and village eggs with brown egg production, and blood and meat spots were very low in white cage eggs $(\mathrm{P}<0.01)$. The yolk ratio was determined in the white eggs of village and cage system $(\mathrm{P}<0.01)$.

The yolk index, which is an indicator of the freshness, ranges between $36-44 \%$ in fresh eggs (Mineki and Kobayashi, 1998). Additionally, higher than $46 \%$ was also expressed as the best value for yolk quality (Sarıca and Erensayin, 2018).

Egg yolk are affected by color, genotype, age, lysine level in feed, production system, fats and antioxidants, vitamin $\mathrm{A}$, calcium intake and some unknown factors with antibiotics and drugs (Sarıca and Erensayın, 2018). Van 
den Brand et al. (2004) and Castellini et al. (2006) reported that yolk color was darker in eggs produced in free-range and organic system compared to cage eggs. Samiullah et al. (2014) reported that darker yolk color was obtained in the traditional cage and free-range system compared to the cage eggs. Hidalgo et al. (2008) reported that yolk color in cage eggs is similar to free-range eggs but darker than organic eggs. Sokolowicz et al. (2018) stated that yolk color of eggs produced in the free-range production system was darker than the closed floor and the organic system.

All albumen traits were differed among production systems $(\mathrm{P}<0.01)$, and the best results were obtained in the majority of the traits in brown cage eggs. Since Haugh Unit evaluates albumen height and weight together, it is used as the most important determinant in egg quality (Sarica and Erensayın, 2018). Castellini et al. (2006) found that Haugh Unit was the highest in eggs produced in enriched organic system when comparing organic, organic plus and cage system. Hidalgo et al. (2008) determined the Haugh Unit of eggs in the market as the highest (69.2) in cage eggs and the lowest (61.0) in organic eggs. They interpreted this finding as organic eggs may be less fresh due to slower marketing. Albumen height and length are the most determinant among egg internal quality traits (Sarica and Erensayın, 2018).

There were differences among production systems in terms of meat and blood-spots levels $(\mathrm{P}<0.01$; Table 1$)$. These values, which are seen at high levels in organic eggs, were followed by free-range, cage-brown, village and cage-white groups. North (1984) found that brown eggs had more blood-spots than white eggs, and that white eggs had 1.5 - 5.5\%; it also states that meat-spots were 0.1 20.0\%. Artan and Durmuş (2015) reported that eggs produced in village, free-range and cage systems did not differ in terms of meat and blood-spots.

\section{Conclusions}

One of the important findings that emerged in the study was obtaining serious fertility levels in eggs produced in the village flocks. Considering early embryonic deaths, the fertility rate, which was determined as $85.0 \%$ in autumn, was $83.3 \%$ in spring and seen as a serious problem considering the methods of marketing these eggs. It should be taken into consideration that embryo development will begin in the eggs when the ambient temperature exceeds $24^{\circ} \mathrm{C}$. Because between the months of May and October, there is a wide period in the region where the eggs are taken, where the average temperature rises above $24^{\circ} \mathrm{C}$. For this reason, there is a need to take precautions that may prevent embryo development in egg storage and placing on the market during these periods, and to raise awareness of consumers on issues that will arise with the storage duration and marketing style of village eggs.

The fact that there were significant differences in the general and shell traits according to the production systems should be considered usual. These differences may be seen depending on the genotype, age and feedstuffs differences and the production system. Mixed color eggs are demanded by consumers in recent years and such a situation is seen in the village flocks. It is important that the shell thickness was lower in village eggs compared to other systems in terms of storage and transportation conditions. In addition, there were problems such as higher shell dirtiness, high shell defects and weak shell breaking strength in village eggs compared to other systems. In terms of these traits, the eggs produced in free-range system come second. It is noteworthy that the high level of shell cleanness in organic eggs. Although eggs may be an important problem in this system, physical shell cleaning is effective in premarketing of eggs. It should be noted that the cuticle layer is completely destroyed. Additionally, very great shell cleanness was obtained in the cage system.

There is a belief among the consumers that the village eggs have a darker yolk color and the same level of dark color is obtained in free-range system. However, according to our results, this belief was not realized.

Although there are differences in albumen traits among the production systems, a non-standard situation regarding albumen quality has not emerged in the study. On the other hand, the level of meat and blood-spots was found high in village eggs and brown laying hen eggs produced in organic, free-range and cage system. The highest value in village chickens is an important finding in terms of relations between welfare and egg quality.

More than $90-95 \%$ of eggs produced in conventional cage systems in Turkey. The exact amount of eggs produced in free-range systems in recent years is not exactly known as it may be mixed with village eggs. Although the processes for coding and placing the eggs on the market according to the production systems took place at the beginning of 2018, it is difficult to distinguish between the free-range system and the supply of village eggs from unregistered farms. It is very difficult to state which production system belongs to village hen eggs. For this reason, "village poultry", which has no standards, should be clearly defined as a production model with certain limitations and those that express commercial value should be recorded. In this way, it creates an unfair competition, has embryo development in the eggs produced in the summer, hens reach all kinds of waste (detergent, medicine, petroleum waste, medicated seeds, fertilizer, septic pits, etc.) and threatening commercial farms with the risk of disease.

\section{Acknowledgments}

In this research article, part of the master's thesis (No: 535351) entitled "Comparison of embryo development and quality of eggs produced in different seasons during the uncontrolled village chickens with commercial eggs", current data and literature were used.

\section{References}

Alders RG, Pym RAE. 2009. Village Poultry: Still Important to Millions, Eight Thousand Years after Domestication. World's Poultry Science Journal, 65: 181-190. doi: 10.1017/S004393 3909000117.

Altan Ö. 2015. Yumurta, Oluşumu, Kalitesi ve Biyoaktif Komponentleri. Ege Üniversitesi Basımevi, İzmir, Turkey (in Turkish).

Artan S, Durmuş İ. 2015. Comparison of egg quality characteristics of produced in village, free range and cage systems. Academic Journal of Agriculture, 4(2): 89-97.

Blokhuis HJ, Van Niekerk TF. 2005. Welfare implications of changes in production systems for laying hens: a European project. Animal Science Papers and Reports, 23(1): 63-69. 
Castellini C, Perella F, Mugnai C, Dal Basco A. 2006. Welfare, productivity and qualitative traits of egg in laying hens reared under different rearing systems. In: Proceedings of the XII European Poultry Conference; Verona, Italy.

De Reu K, Grijspeerdt K, Heyndrickx M, Zoons J, De Baere K, Uyttendaele M, Debevere J, Herman L. 2005. Bacterial eggshell contamination in conventional cages, furnished cages and aviary housing systems for laying hens. British Poultry Science, 46: 149-155. doi: 10.1080/00071660500065 359.

De Reu K, Rodenburg TB, Grijspeerdt K, Messens W, Heyndrickx M, Tuyttens FAM, Sonck B, Zoons J, Herman L. 2009. Bacteriological contamination, dirt, and cracks of eggshells in furnished cages and noncage systems for laying hens: An international on-farm comparison. Poultry Science, 88: 2442-2448. doi: 10.3382/ps.2009-00097.

Ekinci Ö. 2013. Effects of some plant extracts and vitamin supplementation on performance, egg quality and some blood parameters in laying hens at different cage density. PhD Dissertation, Ataturk University, Erzurum, Turkey (in Turkish).

Elibol O. 2018. Embriyo gelişimi ve kuluçka. Tavukçuluk Bilimi, Yetiştirme, Besleme, Hastalıklar. In: Türkoğlu M, Sarıca M (editors) Bey Ofset, Ankara, pp. 151-189.

FAO, 2019. Food and Agriculture Organization of the United Nations. FAOSTAT. Available from: http://www.fao.org/ faostat/en/\#data/QC [Accessed 15 November 2020].

Ferrante V, Lolli S, Vezzoli G, Cavalchini L. 2009. Effect of two different rearing systems (organic and barn) on production performance, animal welfare traits and egg quality characteristics in laying hens. Italian Journal of Animal Science, 8: 165-174. doi: 10.4081/ijas.2009.165.

Hidalgo A, Rossi M, Clerici F, Ratti S. 2008. A market study on the quality characteristics of eggs from different housing systems. Food Chemistry, 106: 1031-1038. doi: 10.1016/j. foodchem.2007.07.019.

Kılıç I, Şimşek E. 2006. The determination effects of indoor climatical conditions in a layer house in Bursa region on interior and exterior egg quality characteristics. Journal of Agricultural Faculty of Bursa Uludag University, 21(2): 31 38.

Kutlu HR. 2018. Tavukların Beslenmesi. Tavukçuluk Bilimi, Yetiştirme, Besleme, Hastalıklar. In: Türkoğlu M, Sarıca M (editors). Bey Ofset, Ankara, pp: 371-518.

Lolli S, Hidalgo A, Alamprese C, Ferrante V, Rossi M. 2013. Layer performances, eggshell characteristics and bone strength in three different housing systems. Biotechnology in Animal Husbandry, 29(4): 591-606. doi: 10.2298/BAH1304 591L.

Mench JA, Sumner DA, Rosen-Molina JT. 2011. Sustainability of egg production in the United States-The policy and market context. Poultry Science, 90: 229-240. doi: 10.3382/ps.201000844.

Mineki M, Kobayashi M. 1998. Microstructural changes in stored hen egg yolk. Japanese Poultry Science, 35(5): 285-294. doi.org/10.2141/jpsa.35.285.

Minelli G, Sirri F, Folegatti E, Meluzzi A, Franchini A. 2007. Egg quality traits of laying hens reared in organic and conventional systems. Italian Journal of Animal Science, 6(1): 728-730. doi: 10.4081/ijas.2007.1s.728.
Mızrak C, Durmuş İ, Kamanlı S, Demirtaş, ŞE., Kalebaşı, S. 2012. Determination egg consumption and consumer habits in Turkey. Turkish Journal of Veterinary and Animal Sciences, 36(6): 592-601. doi: 10.3906/vet-1102-778.

Mostert BE, Bowers EH, Van Der Walt JC. 1995. Influence of different housing systems on the performance of hens of four laying strains. South African Journal of Animal Science, 25(3): 80-86.

North MO. 1984. Commercial Chicken Production Manual. 3rd Edition, Avi Publishing Co., Inc Westport, Connecticut.

Özdamar K. 2002. Paket Programlar ile İstatistiksel Veri Analizi. $7^{\text {th }}$ edition, 1. Kaan Kitabevi, Eskişehir (in Turkish).

Samiullah S, Omar AS, Roberts JR, Chousalkar K. 2014. Effect of production system and flock age on egg quality. In: Proceedings of the 27th Annual Australian Poultry Science Symposium, Sydney, New South Wales, pp: 133-136.

Sarıca M, Erensayın C. 2018. Tavukçuluk Ürünleri. Tavukçuluk Bilimi, Yetiştirme Besleme ve Hastalıklar. In: Türkoğlu M, Sarıca M (editors). Bey Ofset, Ankara, pp: 101-150 (in Turkish).

Sarıca M, Erensoy K, Özsoy A. 2018b. Comparison of Embryo Development and Quality Characteristics of Uncontrolled Village Eggs and Commercial Eggs Produced in Different Seasons. In: Proceedings of the International Poultry Congress of WPSA Turkish Branch, Niğde, Turkey, pp: 140144.

Sarıca M, Türkoğlu M, Yamak US. 2018a. Tavukçuluktaki Gelişmeler ve Türkiye Tavukçuluğu. Tavukçuluk Bilimi Yetiştirme, Besleme ve Hastalıklar. In: Türkoğlu M, Sarıca M (editors). Bey Ofset, Ankara; pp: 1-36 (in Turkish).

Sarıca M. 2017. Alternatif yumurta üretim sistemlerinin karşılaştırılması. In: Proceedings of the Yumurta Zirvesi, 2-5 Kasım, Yumurta Bülteni, Antalya, pp: 11-18 (in Turkish).

Schwarz G, Kobe A, Fries R. 1999. Microflora on eggshells from different housing systems. Archiv für Geflügelkunde, 63(5): 220-224.

Şekeroglu A, Sarıca M, Demir E, Ulutaş Z, Tilki, M, Saatçi M. 2008. The effects of housing system and storage length on the quality of eggs produced by two lines of laying hens. Archiv für Geflügelkunde, 72(3): 106-109.

Şekeroğlu A. 2002. The effects of free-range system on egg productions and egg quality of brown and white layer genotypes. PhD Dissertation, Gaziosmanpaşa University, Tokat, Turkey (in Turkish).

Sokolowicz Z, Krawczyk J, Dykiel M. 2018. The effect of the type of alternative housing system, genotype and age of laying hens on egg quality. Annals of Animal Science, 18(2): 541-555. doi: 10.2478/aoas-2018-0004.

Türkoğlu M, Sarıca M. 2018. Tavuk Genetiği ve Islahı. Tavukçuluk Bilimi, Yetiştirme, Besleme, Hastalıklar. In: Türkoğlu M, Sarıca M (editors). Bey Ofset, Ankara, pp: 324370 (in Turkish).

van Den Brand H, Parmentier HK, Kemp B. 2004. Effects of housing system (outdoor vs cages) and age of laying hens on egg characteristics. British Poultry Science, 45(6): 745-752. doi: 10.1080/00071660400014283.

Wang XL, Zheng JX, Ning ZH, Qu LJ, Xu GY. 2009. Laying performance and egg quality of blue-shelled layers as affected by different housing systems. Poultry Science, 88: 14851492. doi: 10.3382/ps.2008-00417.

Yum-Bir, 2018. Yumurta Üreticileri Merkez Birliği, www.yumbir.org, Ankara (in Turkish). 